\title{
Mekka in the Latter Part of the 19th Century
}

\author{
C. Snouck Hurgronje \\ Leiden: Brill, 2007. 326 pages.
}

The annual spectacle of millions of pilgrims flooding Makkah has captured the imagination of generations of readers. This interest in the hajj, however, has not necessarily produced quality scholarship. From crude ethnographic summaries to careful narratives of spiritual attainment, the literature has been inconsistent at best. Brill's republishing of Dutch scholar Christiaan Snouck Hurgronje's (1857-1936) forgotten work offers the modern reader not only an invaluable window into the hajj as practiced before the age of mass communication, but provides a hitherto neglected discussion on the social, cultural, political, and economic impact that the experience had upon Muslims.

Often lost in the generalizations one finds in descriptions of the annual pilgrimage, the world in which the reader is thrust while reading this book offers a Makkah that is far more culturally dynamic than expected. Hurgronje's world is one filled with cultural and doctrinal variances that are manifested in the different ways in which Muslims worshiped, clothed themselves, and ultimately socialized while in Makkah. In this sense, his careful study of life over the months leading to the hajj exposes the reader to a fluid cultural and economic process that constantly transforms, leaving the reader with the impression that life was not, as the clichés so often try to instill, "timeless." Hurgronje, to his credit, is not interested in retelling the Orientalist trope; rather, he strives to provide a serious ethnographic and historical study.

As Hurgronje himself writes, this is a study to help non-Muslims, especially fellow Dutchmen, understand their Muslim subjects living in the Far East. For this reason, the book's final part focuses exclusively on the Makkan experience of Dutch subjects. In this regard, it is a careful analysis of how Muslims from Java, Borneo, and Sumatra interacted with fellow Muslims; socialized in this cosmopolitan milieu; and adopted numerous personal and collective activities during their stay. That being said, it is especially impressive that this study is not meant to be only a tool for colonial governance.

It is clear that as Hurgronje himself converts to Islam to gain access to Makkah, he is not so much judgmental as offering a refreshing corrective to European stereotypes of Muslims. Throughout this invaluable book, therefore, the reader is confronted with a respectful and repeatedly sympathetic voice, one that reaffirms Islam's universal reach and spiritual depth, a living 
faith that furnished both Dutch subjects and many Muslims of European origin (probably Hurgronje himself) with the kind of intellectual as well as existential sustenance that could not be ignored due to sectarian hostility. Clearly, Hurgronje was not going to play the role of denigrating the people around him for the sake of European self-aggrandizement.

Organized into four parts - "Daily Life in Mekka," "Family Life in Mekka," "Learning in Mekka," and the "Jawaw" - this detailed study takes the reader into a broad range of settings that would otherwise be lost in the traditional travelogue. As his study is as much a corrective exercise as an ethnographical study, he challenges such issues as slavery by providing a rich analysis of otherwise ignored phenomenon in the daily interactions between "slaves" and the rest of society. In respect to slavery, Hurgronje was careful to stress that these human beings - hailing from Central Africa, Ethiopia, and Chechnya - were often engaged in a complex set of relationships with their fellow Muslims that never conformed to the European image of slavery. From the slaves' social mobility after manumission to their central role in the daily social, cultural, and economic lives of the Makkans, the author's complicated treatment of the issue at the very outset sets the stage for a consistently sympathetic and detailed study of Makkah that we rarely find from "western" travelers writing memories about their experiences in "the East."

Equally invaluable as both ethnography and a corrective lesson to his readers is the detailed study of how Makkan society, at all levels, lived off the hajj. The complex interactions between guild members selling their skills to pilgrims arriving by boat, as well as the role of money changers (and money lenders), craftsmen, tricksters, sages, and home owners who rented their homes to visitors all provide rich access to a complex, dynamic society. In the process of explaining the business of the hajj, Hurgronje takes us into the lives of Makkans and pilgrims alike, describing the interior of homes, what the people ate, as well as the incredible variety of clothing patterns that adorned them. The sumptuous life in Makkah, its incredible mixture of human culture, comes to life in this book. People forget that by constantly exchanging goods and eating at the same soup kitchens, pilgrims from around the world introduce new patterns into people's clothing and, more interesting still, new patterns of how Makkans' speak. Linguists, I suspect, will be especially pleased to read this book, as Hurgronje is very careful to point out the variables of the language spoken in various social settings, from the home to the madrasa, that reflect this fusion of humanity. 
Similarly rich are his observations of the Shi'ahs' interactions with the larger Sunni population, which are both astute and balanced. In addition, Hurgronje's detailed explanation of the sexual and marital strategies of the Makkans and of outsiders prove invaluable. His interest in folk medicine, the challenges of raising children, and the mentor/student relationship further add to this wonderful study of late Ottoman Makkah. This book is a fascinating read that offers a plethora of insight into a world that has been more or less obliterated by technology and the modern state. It should become an instant "must-read" to a new generation of scholars and could be adopted, in parts or completely, to teach social history, social linguistics, Islam, and the late nineteenth-century history of the Middle East.

Isa Blumi Assistant Professor of History, Georgia State University Atlanta, Georgia 